\title{
I didn't feel like drinking but I don't know why: The effects of evaluative conditioning on alcohol-related attitudes, craving and behavior
}

Citation for published version (APA):

Houben, K. M. P. I., Schoenmakers, T., \& Wiers, R. W. H. J. (2010). I didn't feel like drinking but I don't know why: The effects of evaluative conditioning on alcohol-related attitudes, craving and behavior. Addictive Behaviors, 35, 1161-1163. https://doi.org/10.1016/j.addbeh.2010.08.012

Document status and date:

Published: 01/01/2010

DOI:

10.1016/j.addbeh.2010.08.012

Document Version:

Publisher's PDF, also known as Version of record

\section{Document license:}

Taverne

Please check the document version of this publication:

- A submitted manuscript is the version of the article upon submission and before peer-review. There can be important differences between the submitted version and the official published version of record.

People interested in the research are advised to contact the author for the final version of the publication, or visit the DOI to the publisher's website.

- The final author version and the galley proof are versions of the publication after peer review.

- The final published version features the final layout of the paper including the volume, issue and page numbers.

Link to publication

\footnotetext{
General rights rights.

- You may freely distribute the URL identifying the publication in the public portal. please follow below link for the End User Agreement:

www.umlib.nl/taverne-license

Take down policy

If you believe that this document breaches copyright please contact us at:

repository@maastrichtuniversity.nl

providing details and we will investigate your claim.
}

Copyright and moral rights for the publications made accessible in the public portal are retained by the authors and/or other copyright owners and it is a condition of accessing publications that users recognise and abide by the legal requirements associated with these

- Users may download and print one copy of any publication from the public portal for the purpose of private study or research.

- You may not further distribute the material or use it for any profit-making activity or commercial gain

If the publication is distributed under the terms of Article $25 \mathrm{fa}$ of the Dutch Copyright Act, indicated by the "Taverne" license above, 


\title{
I didn't feel like drinking but I don't know why: The effects of evaluative conditioning on alcohol-related attitudes, craving and behavior
}

\author{
Katrijn Houben ${ }^{\mathrm{a}, *}$, Tim M. Schoenmakers $^{\mathrm{b}}$, Reinout W. Wiers ${ }^{\mathrm{c}}$ \\ a Maastricht University, The Netherlands \\ b IVO Institute for Addiction Research, The Netherlands \\ c University of Amsterdam, The Netherlands
}

\section{A R T I C L E I N F O}

\section{Keywords:}

Alcohol

Attitudes

Craving

Drinking behavior

Evaluative conditioning

\begin{abstract}
A B S T R A C T
The goal of the present research was to test the value of evaluative conditioning (EC) to unobtrusively change alcohol-related attitudes and drinking behavior. In the EC paradigm, participants had to spot an irrelevant target picture in a series of trials in which many different stimuli were presented. In the experimental condition, beer-related pictures (CSs) were consistently paired with negative words and pictures (USs) in a number of trials. In the control condition, participants were exposed to the same stimuli, but without the critical alcohol-negative pairings. After the EC task, participants participated in an allegedly second experiment in which we measured beer-related attitudes, craving for beer, and actual drinking behavior both during a bogus taste test and during the week following the experiment. Compared to participants in the control condition, participants in the experimental condition showed more negative attitudes toward beer, experienced less craving for beer, and consumed less beer both in the lab during the taste test and outside the lab during the week following the manipulation. These findings suggest that unhealthy drinking behavior may be targeted through EC procedures.
\end{abstract}

(c) 2010 Elsevier Ltd. All rights reserved.

\section{Introduction}

Alcohol abuse and dependence are characterized by a preoccupation with obtaining and drinking alcohol despite devastating physical, social, and occupational consequences. Contemporary dual-process theories stress that this irrational behavior originates because automatic impulses to drink alcohol are not properly regulated (Deutsch \& Strack, 2006; Wiers et al., 2007). Specifically, through encounters with alcohol in daily life, either direct (e.g. drinking in a bar) or indirect (e.g. watching people drink on television), people develop affective associations with alcohol. These affective associations become so well-learned that they are activated whenever alcohol-related cues are encountered and guide behavior in a relatively spontaneous fashion via behavioral schemas. Consistent with this idea, alcohol is indeed associated with positive affect and these associations reliably predict increased levels of alcohol use (e.g., Houben \& Wiers, 2007a,b, 2008; Jajodia \& Earleywine, 2003; McCarthy \& Thompsen, 2006; meta-analysis: Rooke et al., 2008). Hence, immediate affective reactions to alcohol generate a strong impulse to drink alcohol, which often dictates behavior. The

\footnotetext{
* Corresponding author. Clinical Psychological Science, Maastricht University, PO BOX 616, 6200 MD Maastricht, The Netherlands. Tel.: + 31 433881953; fax: + 31 433884196.

E-mail address: K.Houben@maastrichtuniversity.nl (K. Houben).
}

implication is that changing these affective reactions to alcohol may cause a subsequent change in drinking behavior.

A prime candidate for changing the affective value associated with alcohol is evaluative conditioning (EC). The intuitively appealing idea underlying EC is that repeated pairings of a neutral stimulus (conditioned stimulus; CS) with a value laden stimulus (unconditioned stimulus; US) causes the CS to attain the same valence as the US. Importantly, EC does not only serve as a primary origin of attitudes in real life (Olson \& Fazio, 2001), but can also be used to change existing attitudes by introducing new affective associations with attitude objects (i.e., counterconditioning; e.g., Gawronski \& Bodenhausen, 2006; Petty, Tormala, Brinol \& Jarvis, 2006). For instance, Olson and Fazio (2006) demonstrated that repeated pairings of blackgood and white-bad changed racial prejudice without awareness of these repeated pairings. Importantly, the EC procedure that they used presented CS-US pairs simultaneously, interspersed in a rapid stream of randomly presented perceptual events. This procedure has a minimal likelihood of promoting demand characteristics or contingency awareness, and is consistent with real life natural covariations between objects and affect that influence affective reactions despite the fact that attention is directed elsewhere (Olson \& Fazio, 2006).

The present research examined whether a similar EC procedure would succeed in changing alcohol-related attitudes and drinking behavior: Interspersed in a continuous stream of perceptual events, we presented critical pairings of alcohol and affect. In the experimental condition, beer was always paired with negative affect, while a 
control category (water) was consistently paired with positive affect. In the control condition, participants were exposed to the same stimuli, but without the critical pairings of beer and water with affective stimuli. After the EC task, we measured drinking behavior. It was expected that the experimental condition would show a reduction in drinking behavior following the EC procedure compared to the control condition. As in the research by Olson and Fazio (2006), we created two cover stories to keep participants unaware of the EC procedure, and to prevent potential demand effects.

\section{Method}

\subsection{Participants}

Participants were 88 male undergraduate students, who regularly consumed beer. Participants were randomly assigned to the experimental condition (negative beer conditioning; $n=43$ ) or the control condition (no conditioning; $n=45$ ). Mean age was 20.77 years $(S D=2.49)$. On average, participants consumed $19.57(S D=15.40)$ units of alcohol per week (Dutch standard drinking units of $10 \mathrm{~g}$ of alcohol), measured with the time-line follow-back questionnaire (Sobell \& Sobell, 1990). Groups did not differ in age $(t=1.72)$ or alcohol use $(t=.63)$.

\subsection{Procedure}

Participants were invited to participate in an experiment on attention and vigilance (cover story 1, similar to Olson and Fazio, 2006) via posters. During telephone instruction (cover story 2), they were informed that the experiment would only take half of the time we had expected, and that they would therefore receive only half of the incentive. However, if they agreed to participate in another, ostensibly unrelated, experiment on the role of advertising on the perception of alcohol beverages, they would still receive the full incentive. Each experiment was done by another experimenter.

\subsubsection{Experiment 1: Attention and vigilance}

Participants started with the EC task: They were informed that they would be watching a surveillance camera video and that they would see a stream of pictures, occurring one by one or two at a time. Sometimes a meaningless target would appear to which they had to respond (i.e., a different target for each block; e.g., pictures of fishermen or the word 'fishermen'). The task was divided into 6 blocks of 76 trials each. In the experimental condition, each block presented 4 CS-US pairs of beer pictures (CS) with negative IAPS pictures (Lang, Bradley \& Cuthbert, 1995) or negative adjectives (US), 4 CS-US pairs of water pictures with positive IAPS pictures or positive adjectives, and 68 trials with filler stimuli. All beer and water pictures contained drinking people, as to represent the drinking of beer or water. In the control condition, the same CSs and USs were presented, but unpaired with a number of filler trials interspersed. Afterwards, participants received $€ 7.50$ and were asked to wait for the experimenter of the second study.

\subsubsection{Experiment 2: The role of advertising}

The second experimenter explained that this was an experiment about the effects of advertising on subjective perception and taste of beer and water. This allowed us to unobtrusively measure attitudes toward beer and three behavioral measures (in the following order): Attitudes toward beer were assessed with two semantic differentials. Participants indicated on a $100 \mathrm{~mm}$ visual analogue scale (VAS) whether they considered drinking alcohol to be unpleasant-pleasant and boring-fun. Craving for beer was measured with a $100 \mathrm{~mm}$ VAS ranging from "no urge at all" to "an almost irresistible urge" (Kozlowski et al. 1996). A bogus taste test (cf. Field \& Eastwood, 2005) was used to measure actual beer consumption. Participants in

\section{Table 1}

Correlations between the dependent variables: Attitudes toward beer, craving for beer, beer consumption during the taste test, and beer consumption during the week following the manipulation.

\begin{tabular}{lllll}
\hline & Attitudes & Craving & Taste test & Weekly beer use \\
\hline Average weekly alcohol use & $43^{\mathrm{a}}$ & $44^{\mathrm{a}}$ & $.22^{\mathrm{b}}$ & $.74^{\mathrm{a}}$ \\
Attitudes & - & $42^{\mathrm{a}}$ & $.22^{\mathrm{b}}$ & $.40^{\mathrm{a}}$ \\
Craving & & - & $.33^{\mathrm{a}}$ & $.36^{\mathrm{a}}$ \\
Taste test & & - & $.25^{\mathrm{b}}$ \\
Weekly beer use & & - \\
\hline a $=$ Correlation is significant at the 0.01 level (2-tailed). & \\
b = Correlation is significant at the 0.05 level (2-tailed).
\end{tabular}

both conditions were told that they were assigned to the control group in which no advertisement was shown, that was needed to test for differences with a second (non-existing) experimental group that would be shown the advertisement before tasting the drinks. Participants were then presented a glass filled with $250 \mathrm{ml}$ of beer, and a glass filled with $250 \mathrm{ml}$ of mineral water. Participants were instructed to consume as much of each beverage as they wished and judged each drink on four $100 \mathrm{~mm}$ VAS: unpleasant-pleasant, tasteless-strong tasting, bitter-sweet, and flat-gassy (these data were not analyzed as beer consumption was the variable of interest). Afterwards, the amount of beer consumed was measured outside the test room. Drinking behavior in real life was measured with a drinking diary in which participants reported the number of units of beer they had consumed on every day of the following week. Finally, contingency awareness was measured by asking participants (1) whether they had noticed anything strange about the presentation of words and pictures during the surveillance task (general question), and (2) whether they had noticed anything strange about the presentation of certain pictures, such as the ones where people were drinking (specific question). Participants were also asked if they thought the two experiments were related. At the end of the study, participants received $€ 7.5$ as remuneration.

\section{Results}

None of the participants reported awareness of CS-US contingencies when asked generally. When asked whether they specifically noticed anything in the pictures of drinking people, 11 participants reported that they were combined with negative or positive images and words ${ }^{1}$. Further, none of the participants were aware of the connection between the two so-called separate experiments.

All four dependent variables were significantly correlated with each other, and with average weekly alcohol use (see Table 1). The effect of EC on the dependent variables was analyzed using multivariate analysis of covariance (MANCOVA) with condition as a between-subjects factor, and with the average weekly alcohol use as a covariate to control for variability in average alcohol use. Results showed a significant effect of condition, $F(4,82)=2.80, p<.05$, which was further examined using separate univariate analyses of covariance (ANCOVA) for the four dependent variables (one-tailed).

The ANCOVA on attitudes toward alcohol showed a significant covariate effect, $F(1,85)=20.62, p<.001$, and a significant effect of condition, $F(1,85)=3.15, p<.05$, indicating significantly more negative attitudes toward alcohol in the experimental condition compared to the control condition (see Table 2). With respect to craving, results also showed a significant effect of both the covariate, $F(1,85)=21.95$, $p<.001$, and condition, $F(1,85)=2.80, p<.05$, indicating less craving for beer in the experimental condition compared to the control condition (see Table 2). The analyses on consumption during the taste test also revealed a significant effect of both the covariate, $F(1,85)=5.49, p<.05$,

\footnotetext{
${ }^{1}$ When the analyses were performed without these 8 participants, the pattern of results remained generally the same.
} 
Table 2

Estimated marginal means and standard errors for attitudes toward beer, craving for beer, beer consumption during the taste test, and weekly beer consumption following the manipulation, separately per condition.

\begin{tabular}{|c|c|c|c|c|c|c|c|c|}
\hline & \multicolumn{2}{|c|}{ Attitudes } & \multicolumn{2}{|c|}{ Craving } & \multicolumn{2}{|c|}{ Taste test } & \multicolumn{2}{|c|}{ Weekly beer use } \\
\hline & M & SE & M & SE & M & SE & M & SE \\
\hline Experimental & 73.26 & 2.80 & 33.76 & 3.75 & 87.31 & 8.63 & 14.91 & 1.80 \\
\hline Control & 80.22 & 2.74 & 42.52 & 3.66 & 118.43 & 8.43 & 19.45 & 1.76 \\
\hline
\end{tabular}

and condition, $F(1,85)=6.64, p<.01$, indicating that participants in the experimental condition consumed significantly less beer during the taste test than participants in the control condition (see Table 2). Finally, a similar pattern of results was found for beer consumption during the week following the EC manipulation: Both the effect of the covariate, $F(1,85)=108.27, p<.001$, and condition, $F(1,85)=3.24, p<.05$, were significant, indicating that participants in the experimental condition consumed significantly less beer during the week after the manipulation compared to participants in the control condition (see Table 2).

\section{Discussion}

Since affective reactions toward alcohol are a strong correlate of problem-drinking (e.g., Houben \& Wiers, 2007a,b, 2008; Jajodia \& Earleywine, 2003; McCarthy \& Thompsen, 2006; Rooke et al., 2008; see also Deutsch \& Strack, 2006; Wiers et al., 2007), the aim of the present research was to examine whether an EC procedure that repeatedly paired beer-related stimuli with negative affect would be effective in changing attitudes toward beer and drinking behavior. The present findings indeed support this hypothesis: Participants in the experimental condition, who were exposed to the beer-negative pairings, were more negative towards beer, experienced less craving for beer and consumed less beer both during a taste test in the lab and in real life during the week following the manipulation compared to participants in the control condition. Hence, the EC task reduced alcohol-related attitudes as well as drinking behavior for up to a week after the manipulation. Further, the lack of contingency awareness (when asked generally) indicates that these effects were not caused by demand effects.

These findings suggest that EC evaluative conditioning may be an interesting new method to change drinking behavior, especially because effects of evaluative learning are highly resistant to extinction (Olson \& Fazio, 2006; Vansteenwegen, Francken, Vervliet, Declerq, \& Eelen, 2006). Moreover, the effect of EC on attitudes and drinking behavior appears to be robust and independent of the chosen EC procedure, since we have recently also found a similar pattern of results using a different EC paradigm (Houben, Havermans \& Wiers, 2010). Therefore, EC may prove to be a new possibility in the prevention and treatment of alcohol misuse. In order to further examine the usefulness of EC as a potential new treatment strategy, however, future research needs to first examine the value of EC in clinical samples. Second, although the effects on drinking behavior were still present a week after the manipulation, it is unclear how long these effects persisted. Hence, future research also needs to test the longevity of EC effects on both attitudes and behavior.

In sum, the present findings show that drinking behavior can be affected by EC, and therefore suggest that EC may be a beneficial addition to existing intervention techniques. We therefore hope that these initial findings will stimulate future research that aims to extend and replicate these findings in clinical samples to further investigate the potential value of EC for reducing alcohol abuse.

\section{Role of funding sources}

The study was funded by a grant from the Technology Foundation STW (government funding). STW had no role in the study design, collection, analysis or interpretation of the data, writing the manuscript, or the decision to submit the paper for publication.

\section{Contributors}

All authors contributed to the design of the study. Authors Houben and Schoenmakers wrote the protocol, and conducted the statistical analysis. Author Houben wrote the manuscript and all authors contributed to and have approved the final manuscript.

\section{Conflict of interest}

All authors declare that they have no conflicts of interest.

Acknowledgements

This research was supported by a grant from the Technology Foundation STW.

\section{References}

Deutsch, R., \& Strack, F. (2006). Reflective and impulsive determinants of addictive behavior. In R. W. Wiers, \& A. W. Stacy (Eds.), Handbook of Implicit Cognition and Addiction (pp. 45-57). Thousand Oaks, CA: SAGE Publishers.

Field, M., \& Eastwood, B. (2005). Experimental manipulation of attentional bias increases the motivation to drink alcohol. Psychopharmacology, 183(3), 350-357.

Gawronski, B. \& Bodenhausen, G. V. (2006). Associative and propositional processes in evaluation: An integrative review of implicit and explicit attitude change. Pscyhological Bulletin.

Houben, K., Havermans, R. C., \& Wiers, R. W. (2010). Learning to dislike alcohol: Conditioning negative implicit attitudes towards alcohol and its effect on drinking behavior. Psychopharmacology, 211, 79-86.

Houben, K., \& Wiers, R. W. (2007a). Are drinkers implicitly positive about drinking alcohol? Personalizing the alcohol-IAT to reduce negative extrapersonal contamination. Alcohol and Alcoholism, 42, 301-307.

Houben, K., \& Wiers, R. W. (2007b). Personalizing the alcohol-IAT with individualized stimuli: Relationship with drinking behavior and drinking-related problems. Addictive Behaviors, 32, 2852-2864.

Houben, K., \& Wiers, R. W. (2008). Implicitly positive about alcohol? Implicit positive associations predict drinking behavior. Addictive Behaviors, 33, 979-986.

Jajodia, A. \& Earleywine, M. (2003). Measuring alcohol expectancies with the Implicit Association Test. Psychology of Addictive Behaviors, 17, 126-133.

Kozlowski, L. T., Pillitteri, J. L., Sweeney, C. T., Whitfield, K. E., \& Graham, J. W. (1996). Asking questions about urges or cravings for cigarettes. Psychology of Addictive Behaviors, 10(4), 248-260.

Lang, P. J., Bradley, M. M., \& Cuthbert, B. (1995). International affective picture system. Gainesville: University of Florida, Center for Research in Psychophysiology.

McCarthy, D. M., \& Thompsen, D. M. (2006). Implicit and explicit measures of alcohol and smoking cognitions. Psychology of Addictive Behaviors, 20, 436-444.

Olson, M. A., \& Fazio, R. H. (2001). Implicit attitude formation through classical conditioning. Psychological Science, 12(5), 413-417.

Olson, M. A., \& Fazio, R. H. (2006). Reducing automatically-activated racial prejudice through implicit evaluative conditioning. Personality and Social Psychology Bulletin, $32,421-433$.

Petty, R. E., Tormala, Z. L., Brinol, P. \& Jarvis, W. B. G. (2006). Implicit ambivalence from attitude change: An exploration of the PAST model. Journal of Personality and Social Psychology, vol.90(1), 21-41 Jan 2006

Rooke, S. E., Hine, D. W., \& Thorsteinsson, E. B. (2008). Implicit cognition and substance use: A meta-analysis. Addictive Behaviors, 33(1314-1328).

Sobell, L. C., \& Sobell, M. B. (1990). Self-report issues in alcohol abuse: State of the art and future directions.Behavioral Assessment, vol.12(1), 77-90 1990.

Vansteenwegen, D., Francken, G., Vervliet, B., Declerq, A., \& Eelen, P. (2006). Resistance to extinction in evaluative conditioning. Journal of Experimental Psychology: Animal Behavior Processes, 32, 71-79.

Wiers, R. W., Bartholow, B. D., van den Wildenberg, E., Thush, C., Engels, R. C. M. E., Sher, K. J., et al. (2007). Automatic and controlled processes and the development of addictive behaviors in adolescents: A review and a model. Pharmacology, Biochemistry and Behavior, 86, 263-283. 